\title{
Oxygenated Bisabolane Fucosides from Carthamus lanatus $\mathbf{L}$.
}

\author{
Bozhanka Mikhova $^{a^{*}}$, Helmut Duddeck ${ }^{\mathrm{b}}$, Rilka Taskova ${ }^{\mathrm{c}}$, Maya Mitova ${ }^{\mathrm{a}}$, and \\ Kalina Alipieva ${ }^{\mathrm{a}}$ \\ a Institute of Organic Chemistry with Centre of Phytochemistry, Bulgarian Academy of \\ Sciences, 1113 Sofia, Bulgaria. Fax: ++3592-8700225. E-mail: bozhana@orgchm.bas.bg \\ b Institute of Organic Chemistry, University of Hannover, 30167 Hannover, Germany \\ c Institute of Botany, Bulgarian Academy of Sciences, 1113 Sofia, Bulgaria \\ * Author for correspondence and reprint requests \\ Z. Naturforsch. 59c, 244-248 (2004); received July 11/October 2, 2003
}

The aerial parts of Carthamus lanatus (Asteraceae) afforded four new oxygenated bisabolane fucosides, 10-hydroperoxy-bisabola-2,11-diene 7- $O$ - $\beta$-D-fucopyranoside, 11-hydroperoxy-bisabola-2,9-diene 7- $O$ - $\beta$-D-fucopyranoside, 10 -hydroxy-bisabola-2,11-diene $7-O-\beta$-Dfucopyranoside and 11-hydroxy-bisabola-2,9-diene 7-O- $\beta$-D-fucopyranoside together with the known compounds $\alpha$-bisabolol $\beta$-D-fucopyranoside, asperuloside, sitosterol 3-O- $\beta$-D-glucoside and stigmasterol 3-O- $\beta$-D-glucoside. Asperuloside appears to be the second representative of the iridoid monoterpene group found in the plant family Asteraceae, which until recently was considered to lack iridoids. The main constituent $\alpha$-bisabolol fucoside exhibited noticeable antibacterial and cytotoxic activities.

Key words: Carthamus lanatus, Sesquiterpene Fucosides, Asperuloside

\section{Introduction}

Phytochemical studies of Carthamus lanatus L. (Asteraceae) showed the presence of flavonoids (El-Shaer et al., 1998; Novruzov and Shamsizade, 1998), aromatic acids, serotonins (Lahloub et al., 1993), lipids (Demir et al., 1978), amino acids, carbohydrates (Yasuhuko et al., 1979), etc. Until now, sesquiterpene fucosides from the bisabolane (Feliciano et al., 1990a) and eudesmane (Feliciano et al., 1990b) type were isolated. Sedative, antitumor and interferon-inducing activities were reported for C. lanatus (Benedi et al., 1986; Yasuhuko et al., 1979). In continuation of our studies on C. lanatus (Taskova et al., 2002, 2003; Mitova et al., 2003; Stefanov et al., 2003) in the present paper we report data on its terpenoid composition. Antibacterial, antifungal and cytotoxic activity tests were performed on the main sesquiterpenoid constituent $\alpha$-bisabolol $\beta$-D-fucopyranoside.

\section{Experimental}

\section{Plant material}

The aerial parts of $C$. lanatus were collected in July 2001 during the flowering season at the Losen village region, Sofia, Bulgaria. A voucher specimen (No 156639) was identified by Dr. Rilka Taskova and deposited in the Herbarium of the Insti- tute of Botany, Bulgarian Academy of Sciences (SOM).

\section{Extraction and isolation}

The air-dried ground aerial parts (500 g) were extracted with methanol (5 l) at room temperature. The concentrated extract $(78 \mathrm{~g})$ was partitioned between upper and lower layer of hexane/ methanol/water (19:19:2 v/v/v) and the lower layer $(67 \mathrm{~g})$ was extracted with diethyl ether $(5.6 \mathrm{~g}$; water part $59 \mathrm{~g}$ ). The diethyl ether extract was chromatographed on a silica gel (Merck) column with mixtures of ethylacetate/methanol (20:1 to 1:1 $\mathrm{v} / \mathrm{v}$ ) to give pure 5 (fractions 35-40, $1.2 \mathrm{~g}$ ). Fractions $41-44(127 \mathrm{mg})$ were further separated by column chromatography on silica gel with ethylacetate as eluent and a mixture (54 mg, frs 11-15) of $\mathbf{1}$ and $\mathbf{2}$ as well as pure $\mathbf{6}(10 \mathrm{mg})$ were obtained. Fractions 56-58 $(51 \mathrm{mg})$ were additionally purified by SEP-Pak $\mathrm{C}_{18}$ cartridges for rapid sample preparation (Waters, Milford, USA) with methanol and pure $3(20 \mathrm{mg})$ was obtained. Fractions $68-70(211 \mathrm{mg})$ were separated by silica gel column chromatography with chloroform/methanol/ water $(60: 15: 4 \mathrm{v} / \mathrm{v} / \mathrm{v})$ to give a mixture $(26 \mathrm{mg})$ of stigmasterol 3- $O$-glucoside and sitosterol 3- $O$-glucoside (1:4) and pure 4 (20 mg).

Mixture of 10-hydroperoxy-bisabola-2,11-diene 7-O- $\beta$-D-fucopyranoside (1) and 11-hydroperoxy- 
bisabola-2,9-diene 7-O- $\beta$-D-fucopyranoside (2): ESIMS (positive mode): $m / z$ (rel. int.) $=423$ (69) $[\mathrm{M}+\mathrm{Na}]^{+}, 439(48)[\mathrm{M}+\mathrm{K}]^{+}, 407(50)[\mathrm{M}+\mathrm{Na}-16]^{+}$. ${ }^{1} \mathrm{H}$ NMR $\left(400.13 \mathrm{MHz}, \mathrm{CDCl}_{3}\right): \delta=5.84(1 \mathrm{H}, \mathrm{dt}$, $J=16.0,8.0 \mathrm{~Hz}, \mathrm{H}-9$ for 2), $5.55(1 \mathrm{H}, \mathrm{d}, J=$ $16.0 \mathrm{~Hz}, \mathrm{H}-10$ for 2), 5.34 (br s, H-2), 4.94 (br s, $\mathrm{H}_{2}-12$ for $\left.\mathbf{1} / \mathbf{1}^{\prime}\right), 4.40\left(\mathrm{~d}, J=7.1 \mathrm{~Hz}, \mathrm{H}-1^{\prime}\right), 4.15(\mathrm{~m}$, $\mathrm{H}-10$ for $\left.\mathbf{1} / \mathbf{1}^{\prime}\right), 2.43(1 \mathrm{H}, \mathrm{dd}, J=14.5,6.4 \mathrm{~Hz}, \mathrm{H}-8 \mathrm{a}$ for 2), $2.32(1 \mathrm{H}, \mathrm{dd}, J=14.5,7.0 \mathrm{~Hz}, \mathrm{H}-8 \mathrm{~b}$ for 2$)$, 1.72 and $1.74\left(\mathrm{~s}, \mathrm{CH}_{3}-13\right.$ for $\left.\mathbf{1} / \mathbf{1}^{\prime}\right), 1.64\left(\mathrm{~s}, \mathrm{CH}_{3}-15\right)$, $1.28\left(3 \mathrm{H}, \mathrm{s}, \mathrm{CH}_{3}-12\right.$ for 2$), 1.27\left(3 \mathrm{H}, \mathrm{s}, \mathrm{CH}_{3}-13\right.$ for 2), 1.27 and $1.26\left(\mathrm{~d}, J=6.4 \mathrm{~Hz}, \mathrm{CH}_{3}-6^{\prime}\right), 1.16$ and 1.12 (s, $\left.\mathrm{CH}_{3}-14\right)$. $\quad{ }^{13} \mathrm{C}-\mathrm{NMR} \quad(100.62 \mathrm{MHz}$, $\left.\mathrm{CDCl}_{3}\right)$ : see Table I.

10-Hydroxy-bisabola-2,11-diene 7-O- $\beta$-D-fucopyranoside $\left(\mathbf{3} / \mathbf{3}^{\prime}\right)$ : ESIMS (positive mode): $\mathrm{m} / \mathrm{z}$ (rel. int.) $=407(63)[\mathrm{M}+\mathrm{Na}]^{+}, 423(21)[\mathrm{M}+\mathrm{K}]^{+}$, $385[\mathrm{M}+\mathrm{H}]^{+}(15) . \quad-{ }^{1} \mathrm{H}$ NMR $(250.13 \mathrm{MHz}$, $\left.\mathrm{CDCl}_{3}\right): \delta=5.34$ (br s, H-2), 4.85, 4.70 (br s, $\left.\mathrm{H}_{2}-12\right), 4.07$ (m, H-10), 1.67, 1.64 (s, $\left.\mathrm{CH}_{3}-13\right), 1.66$ $\left(\mathrm{s}, \mathrm{CH}_{3}-15\right), 1.16\left(\mathrm{~s}, \mathrm{CH}_{3}-14\right), 1.28(\mathrm{~d}, J=6.8 \mathrm{~Hz}$, $\left.\mathrm{CH}_{3}-6^{\prime}\right)$. ${ }^{13} \mathrm{C}$ NMR $\left(62.8 \mathrm{MHz}, \mathrm{CDCl}_{3}\right.$,): see Table I.

11-Hydroxy-bisabola-2,9-diene 7-O- $\beta$-D-fucopyranoside (4): ESIMS (positive mode): $\mathrm{m} / z$ (rel. int.) $=407[\mathrm{M}+\mathrm{Na}]^{+}, 423[\mathrm{M}+\mathrm{K}]^{+} .-{ }^{1} \mathrm{H} \mathrm{NMR}$ $\left(250.13 \mathrm{MHz}, \mathrm{CDCl}_{3}\right): \delta=5.82(1 \mathrm{H}, \mathrm{dt}, J=16.0$, $7.0 \mathrm{~Hz}, \mathrm{H}-9), 5.60$ (1H, d, $J=16.0 \mathrm{~Hz}, \mathrm{H}-10), 5.34$ (1H, br s, H-2), 2.35-2.15 (2H, m, $\left.\mathrm{H}_{2}-8\right), 1.66(3 \mathrm{H}$, $\left.\mathrm{s}, \mathrm{CH}_{3}-15\right), 1.30\left(3 \mathrm{H}, \mathrm{s}, \mathrm{CH}_{3}-13\right), 1.28(\mathrm{~d}, J=$ $\left.6.8 \mathrm{~Hz}, \mathrm{CH}_{3}-6^{\prime}\right) .-{ }^{13} \mathrm{C} \mathrm{NMR}\left(62.8 \mathrm{MHz}, \mathrm{CDCl}_{3}\right)$ : see Table I.

\section{Photooxidation of $\mathbf{5}$ to $\mathbf{1}$ and $\mathbf{2}$ and further reduction to $\mathbf{3}$ and $\mathbf{4}$}

5 (60 mg) was dissolved in $15 \mathrm{ml}$ acetone and Bengal rose $(1.5 \mathrm{mg})$ and pyridine $(0.5 \mathrm{ml})$ were added. The reaction mixture was illuminated and air bubbled through it for $2 \mathrm{~h}$. The reaction product was purified by PTLC on silica gel with ethylacetate/hexane $(10: 2 \mathrm{v} / \mathrm{v})$ to afford a mixture of $\mathbf{1}$ and $2(30 \mathrm{mg})$. NaI was added to the mixture (17 mg, 1:1 mol equiv.) and left for $48 \mathrm{~h}$. The reaction was monitored by TLC and the product $(47 \mathrm{mg})$ was elucidated as a mixture of $\mathbf{3}$ and $\mathbf{4}$.

\section{Antibacterial assay}

Antimicrobial activity was studied by the modified disk diffusion method of Kujumgiev et al. (1993). The Gram-positive bacteria Staphylococcus aureus, the Gram-negative bacteria Escheri- chia coli and the fungus Candida albicans were used. 5 was tested at $1.36 \mu \mathrm{m} /$ disk $(500 \mu \mathrm{g} / \mathrm{disk})$ using streptomycin as a positive control at $0.134 \mu \mathrm{m} /$ disk $(100 \mu \mathrm{g} /$ disk) (inhibitory zone $28.0 \pm$ $1.0 \mathrm{~mm}$ ). The obtained results (Table II) were the mean of three replications. The absence of activity was evaluated by a diameter of the inhibitory zone less than $10 \mathrm{~mm}$.

\section{Cytotoxicity assay}

The brine shrimp (Artemia salina) assay (Table II) was performed in triplicate with appropriate amounts of $\mathbf{5}$ dissolved in DMSO (1\% final volume) using 10 freshly hatched larvae, suspended in $5 \mathrm{ml}$ artificial sea water (Solis et al., 1993). Concentrations of 2.7, 0.27, 0.027 and $0.0027 \mu \mathrm{M}$ were used. For each dose tested deaths and survivors were counted after $24 \mathrm{~h}$ and data statistically analyzed, which affords $\mathrm{LD}_{50}$ values with $95 \%$ confidence intervals. Caffeic acid phenethyl ester (CAPE) was used as active reference substance.

\section{Results and Discussion}

The methanol extract of aerial parts of C. lanatus was partitioned between hexane/methanol/ water (19:19:2 v/v/v) and the diethyl ether extract of the water/alcoholic part was separated by combination of chromatographic techniques. Four new oxygenated bisabolane fucosides (1-4; Fig. 1) in<smiles>[R]C1=C(C)CCC([C@@](C)(CC(=C)C)OC(C)=O)C1</smiles><smiles>CO[C@](C)(C/C=C/C(C)(C)O)C1CC=C(C)CC1</smiles>

$1 \mathrm{R}=\mathrm{OH}$ $2 \mathrm{R}=\mathrm{H}$

$$
\begin{aligned}
& 3 \mathrm{R}=\mathrm{OH} \\
& 4 \mathrm{R}=\mathrm{H}
\end{aligned}
$$
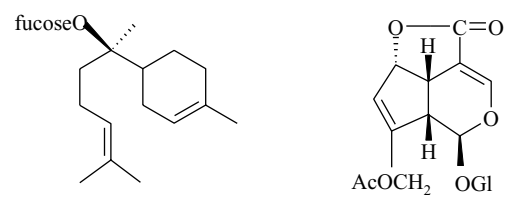

5

Fig. 1. 10-Hydroperoxy-bisabola-2,11 diene 7-O- $\beta$-Dfucopyranoside* (1); 11-hydroperoxy-bisabola-2,9diene 7-O- $\beta$-D-fucopyranoside* (2); 10-hydroxy-bisabola-2,11diene 7-O- $\beta$-D-fucopyranoside* (3); 11-hydroxy-bisabola2,9-diene 7-O $\beta$-D-fucopyranoside* (4); $\alpha$-bisabolol $\beta$-Dfucopyranoside; (5); asperuloside (6).

$*$ New compounds. 
addition to four known compounds were afforded. By means of spectroscopic methods and comparison with literature data the latter compounds were identified as the known sesquiterpenoid fucoside $\alpha$-bisabolol $\beta$-D-fucopyranoside (5) (Feliciano et al., 1990a), the iridoid glucoside asperuloside (6) (ElNaggar and Beal, 1980) and two phytosterol glucosides, sitosterol 3-O- $\beta$-D-glucoside and stigmasterol 3-O- $\beta$-D-glucoside (Alam et al., 1996). The phytosterol glucosides and asperuloside are reported for the first time for $C$. lanatus.

Compounds $\mathbf{1}$ and $\mathbf{2}$ were with comparable polarity and obtained as an inseparable mixture. The ESIMS (positive mode) showed molecular clusters at $m / z 423[\mathrm{M}+\mathrm{Na}]^{+}$and $439[\mathrm{M}+\mathrm{K}]^{+}$indicating a molecular mass of 400 for both compounds. The peak at $407[\mathrm{M}+\mathrm{Na}-16]^{+}$due to the elimination of oxygen from the cluster ion indicated the peroxide nature of $\mathbf{1}$ and 2 . The ${ }^{1} \mathrm{H}$ (experimental) and ${ }^{13} \mathrm{C}$ NMR (Table I) data of $\mathbf{1}$ and $\mathbf{2}$ showed that they were derivatives of the main sesquiterpenoid constituent in the plant $\alpha$-bisabolol fucopyranoside (5) containing a bisabolane skeleton, a fucoside moiety and a different side chain. Moreover, 1 appeared to be an epimeric mixture at $\mathrm{C}-10$. The structures of $\mathbf{1}$ and $\mathbf{2}$ were elucidated by 2D NMR COSY, HMQC and HMBC spectra. The charac-

Table I. ${ }^{13} \mathrm{C}$ NMR spectral data for compounds $\mathbf{1 - 5}$ in $\mathrm{CDCl}_{3}$.

\begin{tabular}{rcrlrr}
\hline $\mathrm{C}$ & $\mathbf{1 / 1}^{\prime \mathrm{a}}$ & $\mathbf{2}$ & $\mathbf{3 / 3}^{\prime \mathrm{a}}$ & $\mathbf{4}$ & $\mathbf{5}$ \\
\hline 1 & $27.1 \mathrm{t}$ & $27.1 \mathrm{t}$ & $28.0 / 28.5 \mathrm{t}$ & $26.9 \mathrm{t}$ & $26.8 \mathrm{t}$ \\
2 & $120.3 \mathrm{~d}$ & $120.3 \mathrm{~d}$ & $120.3 \mathrm{~d}$ & $120.2 \mathrm{~d}$ & $120.5 \mathrm{~d}$ \\
3 & $134.4 \mathrm{~s}$ & $134.4 \mathrm{~s}$ & $134.5 \mathrm{~s}$ & $134.1 \mathrm{~s}$ & $134.3 \mathrm{~s}$ \\
4 & $31.9 \mathrm{t}$ & $31.9 \mathrm{t}$ & $30.9 \mathrm{t}$ & $30.6 \mathrm{t}$ & $30.9 \mathrm{t}$ \\
5 & $23.5 \mathrm{t}$ & $23.5 \mathrm{t}$ & $23.5 \mathrm{t}$ & $22.4 \mathrm{t}$ & $23.4 \mathrm{t}$ \\
6 & $41.4^{\mathrm{b}} \mathrm{d}$ & $41.6^{\mathrm{b}} \mathrm{d}$ & $41.0 / 41.1 \mathrm{~d}$ & $41.4 \mathrm{~d}$ & $40.9 \mathrm{~d}$ \\
7 & $82.1 \mathrm{~s}$ & $82.1 \mathrm{~s}$ & $82.2 / 82.0 \mathrm{~s}$ & $81.7 \mathrm{~s}$ & $81.8 \mathrm{~s}$ \\
8 & $32.4 \mathrm{t}$ & $40.3 \mathrm{t}$ & $33.7 \mathrm{t}$ & $39.8 \mathrm{t}$ & $37.7 \mathrm{t}$ \\
9 & $23.5 \mathrm{t}$ & $126.5 \mathrm{~d}$ & $27.2 / 27.0 \mathrm{t}$ & $122.2 \mathrm{~d}$ & $21.6 \mathrm{t}$ \\
10 & $89.2 \mathrm{~d}$ & $136.7 \mathrm{~d}$ & $75.6 \mathrm{~d}$ & $140.3 \mathrm{~d}$ & $124.8 \mathrm{~d}$ \\
11 & $143.7 / 143.8 \mathrm{~s}$ & $81.4 \mathrm{~s}$ & $147.5 \mathrm{~s}$ & $70.4 \mathrm{~s}$ & $131.0 \mathrm{~s}$ \\
12 & $113.3 / 113.6 \mathrm{t}$ & $24.4^{\mathrm{d}} \mathrm{q}$ & $110.4 / 110.8 \mathrm{t}$ & $29.4 \mathrm{q}$ & $17.7 \mathrm{q}$ \\
13 & $17.5 / 17.7 \mathrm{q}$ & $24.7^{\mathrm{d}} \mathrm{q}$ & $17.9 / 18.1 \mathrm{q}$ & $29.4 \mathrm{q}$ & $25.6 \mathrm{q}$ \\
14 & $19.7^{\mathrm{c}} \mathrm{q}$ & $19.3^{\mathrm{c}} \mathrm{q}$ & $19.4 / 19.6 \mathrm{q}$ & $19.4 \mathrm{q}$ & $20.1 \mathrm{q}$ \\
15 & $23.4 \mathrm{q}$ & $23.4 \mathrm{q}$ & $23.4 \mathrm{q}$ & $23.1 \mathrm{q}$ & $23.3 \mathrm{q}$ \\
$1^{\prime}$ & $97.3 \mathrm{~d}$ & $97.3 \mathrm{~d}$ & $96.9 / 97.0 \mathrm{~d}$ & $97.0 \mathrm{~d}$ & $97.0 \mathrm{~d}$ \\
$2^{\prime}$ & $71.7 \mathrm{~d}$ & $71.7 \mathrm{~d}$ & $71.6 \mathrm{~d}$ & $71.2 \mathrm{~d}$ & $71.5 \mathrm{~d}$ \\
$3^{\prime}$ & $71.7 \mathrm{~d}$ & $71.7 \mathrm{~d}$ & $71.8 \mathrm{~d}$ & $71.2 \mathrm{~d}$ & $71.7 \mathrm{~d}$ \\
$4^{\prime}$ & $74.1 \mathrm{~d}$ & $74.1 \mathrm{~d}$ & $74.1 \mathrm{~d}$ & $73.8 \mathrm{~d}$ & $74.3 \mathrm{~d}$ \\
$5^{\prime}$ & $70.3 \mathrm{~d}$ & $70.3 \mathrm{~d}$ & $70.4 \mathrm{~d}$ & $69.9 \mathrm{~d}$ & $70.2 \mathrm{~d}$ \\
$6^{\prime}$ & $16.5 \mathrm{q}$ & $16.5 \mathrm{q}$ & $16.6 \mathrm{q}$ & $16.2 \mathrm{q}$ & $16.5 \mathrm{q}$ \\
\hline
\end{tabular}

Obtained as a mixture of isomers at C-10.

$\mathrm{b}-\mathrm{d}$ Interchangeable signals. teristic signals for the side chain of $\mathbf{1}$ included unsaturation at C-11 $\left(\delta_{\mathrm{c}} 143.7 / 143.8 \mathrm{~s}\right)$ and a pair of exomethylene protons at C-12 $\left(\delta_{\mathrm{H}} 4.94\right)$ corresponding to two signals in the ${ }^{13} \mathrm{C}$ spectrum at $\delta 113.3 / 113.6 \mathrm{t}$, an allylic methyl group $\left(\delta_{\mathrm{H}} 1.72 /\right.$ $\left.1.74, \mathrm{~s} ; \delta_{\mathrm{C}} 17.5 / 17.7 \mathrm{q}\right)$ and a signal for C-10 at $\delta_{\mathrm{c}} 89.2 \mathrm{~d}$, a value typical for a hydroperoxinated carbon. The differences in the ${ }^{1} \mathrm{H}$ and ${ }^{13} \mathrm{C}$ NMR spectra for both isomers were too small to make conclusions about their stereochemistry. The second peroxide 2 possessed in the side chain a twosubstituted double bond $\left(\delta_{\mathrm{H}} 5.84 \mathrm{dt}, J=16.0\right.$, $8.0 \mathrm{~Hz}$ and $5.55 \mathrm{~d}, J=16.0 \mathrm{~Hz} ; \delta_{\mathrm{c}} 126.5 \delta$ and 136.7 $\mathrm{d}$, respectively) and a deshielded carbon signal at $\delta 81.4 \mathrm{~s}$, consistent with a hydroperoxide group at the position $\mathrm{C}-11$. The coupling constants ${ }^{3} J_{\mathrm{H} 9-\mathrm{H} 10}$ $(16.0 \mathrm{~Hz})$ in 2 indicated trans configuration at the double bond.

The aglycones of $\mathbf{1}$ and $\mathbf{2}$ were isolated previously from Schistostephium crategifolium (Bohlmann et al., 1983) and Achillea odorata (Barrero et al., 1990) but only scarce ${ }^{1} \mathrm{H}$ NMR data were reported for them (Bohlmann et al., 1983). In addition, the chemical shifts for the side chain showed a correspondence with those of the bisabolane hydroperoxides from Rosa rugosa (Hashidoko et al., 1991) and Alpina densibracteata (Zingiberaceae) (Sy and Brown, 1997).

Finally, the structures were confirmed by chemical transformation of the main sesquiterpenoid fucoside 5, which was photooxidized to yield a mixture of hydroperoxides (Scheme 1). They were proved to be identical with $\mathbf{1}$ and $\mathbf{2}$ on the basis of the ${ }^{1} \mathrm{H}$ and ${ }^{13} \mathrm{C}$ NMR data. Further reduction of the reaction mixture yielded the corresponding alcohols 3 and 4. Previously, Feliciano et al. (1990a) performed photooxidation of the triacetate of $\mathbf{5}$ to obtain the acetates of $\mathbf{1}$ and $\mathbf{2}$, which were further

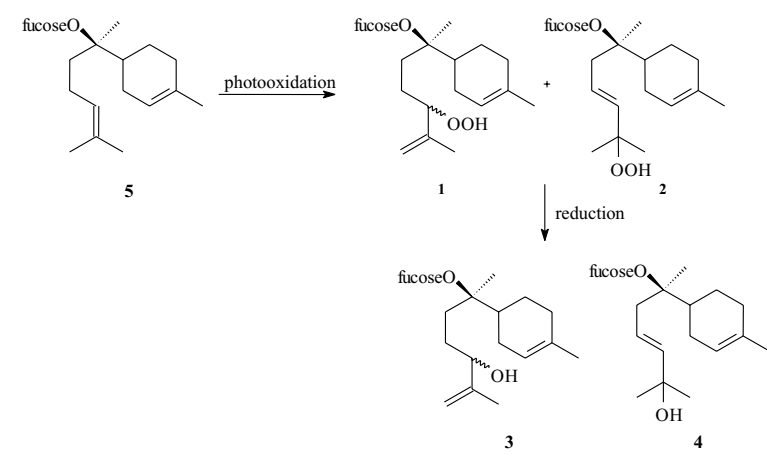

Scheme 1. 
reduced to acetates of the alcohols 3 and 4 . However, no spectral data were reported for the peroxide acetates of $\mathbf{1}$ and $\mathbf{2}$. Based on the above data $\mathbf{1}$ and $\mathbf{2}$ are deduced to be 10-hydroperoxy-bisabola-2,11-diene 7-O- $\beta$-D-fucopyranoside and 11 hydroperoxy-bisabola-2,9-diene $7-O-\beta$-D-fucopyranoside. The isolated hydroperoxides are probably derived from $\mathbf{5}$, but we suggest them being metabolites of $C$. lanatus and not artefacts, because they were found in fresh leaves.

In addition to the bisabolane hydroperoxides, another two compounds $\mathbf{3}$ and $\mathbf{4}$ were also obtained. The NMR data (Table I and Experimental) were indicative of the alcoholic equivalent of the hydroperoxides $\mathbf{1}$ and $\mathbf{2}$. Both compounds gave similar ESIMS spectra with clusters at $\mathrm{m} / \mathrm{z} 407$ $[\mathrm{M}+\mathrm{Na}]^{+}$and $423[\mathrm{M}+\mathrm{K}]^{+}$and protonated molecular ions at $m / z 385[\mathrm{M}+\mathrm{H}]^{+}$. The NMR spectral data showed similarity to those of $\mathbf{1}$ and $\mathbf{2}$. Some differences typical for alcohol functions rather than peroxide ones (Appendino et al., 1985; Sy and Brown, 1997) were observed. Thus, the ${ }^{13} \mathrm{C}$ chemical shifts of compound 3 at the C-10 position (including the neighbouring positions) were consistent with a 10-OH group (C-10: $\delta_{\mathrm{c}} 75.6 \mathrm{~d}$; C-11: $147.5 \mathrm{~s}$; C-12: $110.4 / 110.8 \mathrm{t}$ ) and for 4 with a $11-\mathrm{OH}$ group (C-9: $\delta_{\mathrm{c}} 122.2 \mathrm{~d}$; C-10: $140.3 \mathrm{~d}$; C-11: $70.4 \mathrm{~d}$; C-12: 29.4 q), respectively. Compound 3, like 1, appeared to be a mixture of epimers at C-10.

The NMR data of the aglycone part of $\mathbf{3}$ and $\mathbf{4}$ showed resemblance with the isolated from Achillea odorata 2,11-bisaboladiene-7,10-diol and 2,9bisaboladiene-7,11-diol (Barrero et al., 1990) and the NMR data of the side chain, with those of 7,11dihydroxy-2,11-bisaboladiene-15-oic acid methyl ester and 7,10-dihydroxy-2,11-bisaboladiene-15- oic acid methyl ester from Rosa rugosa (Hashidoko et al., 1993).

Furthermore as stated above, $\mathbf{1}$ and $\mathbf{2}$ by reduction with $\mathrm{NaI}$ afforded alcohols, which were proved to be identical with 3 and 4 (Scheme I). Therefore, the structures of $\mathbf{3}$ and $\mathbf{4}$ were elucidated as 10 -hydroxy-bisabola-2,11-diene 7-O- $\beta$-Dfucopyranoside and 11-hydroxy-bisabola-2,9-diene 7-O- $\beta$-D-fucopyranoside.

Unexpectedly, compound $\mathbf{6}$ was assigned as the iridoid glucoside, asperuloside. Until recently, the Asteraceae were considered to lack iridoids. However, Changzeng and Dequan (1997) isolated a secoiridoid from Aster auriculatus and now asperuloside is isolated from Carthamus lanatus. Grayer et al. (1999) assumed that the gene to produce iridoids is latent but not lost in the Asteraceae and could be switched on if it is necessary or by chance. We presume that the iridoid metabolic pathway still exists in the representatives of the family resulting in production of compounds in very small amounts, which are difficult to be detected. Apparently, most of the available isoprane precursors are used in the synthesis of other terpenoids (sesquiterpenoids) with a larger potential as protective substances in the plants.

\section{Biological activity}

The aglycone of 5, $\alpha$-bisabolol, is a well-known bioactive compound with anti-inflammatory, bactericidal and anti-mycotic properties (Harborne et al., 1999). To our knowledge no data are reported for $\alpha$-bisabolol $\beta$-D-fucopyranoside (5) which appears as the main sesquiterpene glycoside of C. lanatus.

Table II. Antimicrobial activity and cytotoxicity of $\alpha$-bisabolol $\beta$-D-fucopyranoside $(\mathbf{5})^{\mathrm{a}}$.

\begin{tabular}{|c|c|c|c|c|}
\hline Sample & $\begin{array}{l}\text { Antin } \\
\text { Staphylococcus } \\
\text { aureus } \\
\text { Zone of inhil }\end{array}$ & $\begin{array}{c}\text { crobial activity } \\
\text { Escherichia } \\
\text { coli } \\
\text { tion in diamet }\end{array}$ & $\begin{array}{l}\text { Candida } \\
\text { albicans } \\
{[\mathrm{mm}]}\end{array}$ & $\begin{array}{l}\text { Cytotoxycity } \\
\mathrm{LD}_{50}[\mu \mathrm{M}]\end{array}$ \\
\hline 5 & $38.7 \pm 1.1$ & $--^{\mathrm{b}}$ & - & $0.0760 \pm 0.0288$ \\
\hline Reference $^{c}$ & $28.0 \pm 1.0$ & - & - & $0.0025 \pm 0.0003$ \\
\hline
\end{tabular}


5 was studied for antibacterial and antifungal activity by the modified disk diffusion method (Kujumgiev et al., 1993) The Gram-positive bacteria Staphylococcus aureus, the Gram-negative bacteria Escherichia coli and the fungus Candida albicans were used as test microorganisms. Action of significance against $S$. aureus $(38.7 \pm 1.1)$ was detected (see Table II). No activity against E. coli and $C$. albicans was shown. The cytotoxicity of $\mathbf{5}$ was investigated by the Artemia salina assay (Solis et al., 1993) and considerable activity was eval- uated $\left(\mathrm{LD}_{50} \quad 0.0760 \pm 0.0288 \mu \mathrm{M}, \quad 27.97 \quad \pm\right.$ $10.67 \mu \mathrm{g} / \mathrm{ml})$.

The pure $\alpha$-bisabolol $\beta$-D-fucopyranoside (5) showed significantly higher antimicrobial and cytotoxic activity than the previously studied diethyl ether fraction of the methanol extract (Taskova et al., 2002), where $\mathbf{5}$ is the main constituent.

\section{Acknowledgement}

This research was supported by Deutsche Forschungsgemeinschaft (DFG).
Alam M., Chopra N., Ali M., and Niwa M. (1996), Oleanen and stigmasterol derivatives from Ambroma augusta. Phytochemistry 41, 1197-1200.

Appendino G., Gariboldi P., and Menichini F. (1985), Oxygenated nerolidol derivatives from Artemisia alba. Phytochemistry 24, 1729-1733.

Barrero A. F., Alvarez-Manzaneda E. J., and AlvarezManzaneda R. (1990), Bisabolene derivatives and other constituents from Achillea odorata. Phytochemistry 29, 3213-3216.

Benedi J., Iglesias I., Manzanares J., and Zaragoza F. (1986), Preliminary pharmacological studies of Carthamus lanatus L. Pl. Med. et Phytoth. 20, 25-30.

Bohlmann F., Jakupovic J., Ahmed M., and Schuster A. (1983), Sesquiterpene lactones and other constituents from Schistostephium species. Phytochemistry 22, $1623-1636$.

Changzeng W. and Dequan Y. (1997), Diterpenoid, sesquiterpenoid and secoiridoid glucosides from Aster auriculatus. Phytochemistry 47, 1483-1487.

Demir L., Nedim A., and Marquard R. (1978), The fatty acid pattern and tocopherol content as different characteristics of Carthamus species found in Turkey. Angew. Bot. 52, 313-319.

El-Naggar L. and Beal J. (1980), Iridoids. A review. J. Nat. Prod. 43, 649-707.

El-Shaer N., Shaaban E., Abou-Karam M., and El-Din A. (1998), Flavonoids from Carthamus lanatus. Alex. J. Pharm. Sci. 12, 23-26.

Feliciano A., Medarde M., Del Rey B., Del Corral J., and Barrero A. (1990a), Bisabolane related glycosides from Carthamus lanatus. Phytochemistry 29, 645-648 (and ref. cited therein).

Feliciano A., Medarde M., Del Rey B., Del Corral J., (and Barrero A. (1990b), Eudesmane glycosides from Carthamus lanatus. Phytochemistry 29, 3207-3211 (and ref. cited therein).

Grayer G., Chase M., and Simmonds M. (1999), A comparison between chemical and molecular characters for the determination of phylogenetic relationships among plant families: An appreciation of Hegnauer's "Chemotaxonomie der Pflanzen". Biochem. Syst. Ecol. 27, 369-393.
Harborne J. B., Baxter H., and Mass G. P. (1999) Phytochemical Dictionary. A Handbook of Bioactive Compounds from Plants. Taylor \& Francis Ltd., London.

Hashidoko Y., Tahara S., Iwaya N., and Mizutani J. (1991), Highly oxigenated bisabolanoids in Rosa rugosa leaves. Z. Naturforsch. 46c, 357-363.

Hashidoko Y., Tahara Y., and Mizutani J. (1993), Sesquiterpenoids from Rosa rugosa leaves. Phytochemistry 32, 387-390.

Kujumgiev A., Bankova V., Ignatova A., and Popov S. (1993), Antibacterial activity of propolis, some of its components and their analogs. Pharmacie 48, 785-786.

Lahloub M., Amor M., El-Khajaat S., and Haraz F. (1993), A new serotonin derivative from seeds of Carthamus lanatus L. Mans. J. Pharm. Sci. 9, 234-243.

Mitova M., Taskova R., Popov S., Berger R., Krings U., and Handjieva N. (2003), GC/MS analysis of some bioactive constituents from Carthamus lanatus L. Z. Naturforsch. 58c, 697-703.

Novruzov E., and Shamsizade L. (1998), Anthocyans of Carthamus species. Chem. Nat. Comp. 34, 514-515.

Solis P., Wright C., Anderson M., Gupta M., and Philippson J. (1993), A microwell cytotoxicity assay using Artemia salina (brine shrimp). Planta Med. 59, 250252.

Stefanov K., Taskova R., Mitova M., Topashka M., Seizova K., and Duddeck H. (2003), Analysis and biological actitvity of the lipid extract of Carthamus lanatus L. Compt. Rend. Acad. Bulg. Sci. 56, 13-18.

Sy L.-K. and Brown G. D. (1997), Oxygenated bisabolanes from Alpina densibracteata Phytochemistry 45, 537-544.

Taskova R., Mitova M., Najdenski H., Tzvetkova I., and Duddeck H. (2002), Antimicrobial activity and cytotoxicity of Carthamus lanatus. Fitoterapia 73, 540543.

Taskova R., Mitova M., Mikhova B., and Duddeck H. (2003), Bioactive phenolics from Carthamus lanatus L. Z. Naturforsch. 58c, 704-707.

Yasuhuko K., Kanagawa Y., Seishi K., and Takashi H. Wasserlöslicher Interferoninduktor, Verfahren zu seiner Gewinnung und dessen Verwendung. Ger. Offen. 3,004,018 Appl. 07, Feb. 1979. 